\title{
BELAJAR BERKOMUNIKASI DAN KOMUNIKASI UNTUK BELAJAR DALAM PEMBELAJARAN MATEMATIKA
}

Oleh:

\author{
Karman Lanani \\ Dosen FKIP, Universitas Khairun Ternate \\ karmanlanani@gmail.com
}

\begin{abstract}
Kegiatan pembelajaran merupakan proses komunikasi untuk menyampaikan pesan dari pendidik kepada peserta didik, bertujuan agar pesan dapat diterima dengan baik dan berpengaruh terhadap pemahaman serta terbentuknya perubahan tingkah laku. Komunikasi edukatif dalam pembelajaran matematika menjadi faktor yang juga berpengaruh terhadap keberhasilan kegiatan pembelajaran matematika. Komunikasi pembelajaran dapat efektif apabila terdapat aliran respon informasi dua arah antara komunikator dan komunikan. Setidaknya terdapat lima aspek yang perlu dipahami dalam membangun komunikasi yang efektif, yaitu: kejelasan, ketepatan, konteks, sistematika yang jelas, dan budaya komunikator atau komunikan. Mengkomunikasikan matematika, diperlukan kemampuan berkomunikasi yang efektif. Baik guru maupun siswa dalam pembelajaran matematika diharapkan mampu mengomunikasikan pikiran matematisnya secara lisan dan tertulis, secara koheren dan jelas, menggunakan bahasa matematika untuk mengekspresikan gagasannya secara tepat, mengelola pikiran matematisnya melalui komunikasi, menganalisis dan mengevaluasi pikiran matematis siswanya. Hal ini dimaksudkan agar siswa berkemampuan komunikasi secara efektif dalam : (1) menghubungkan benda nyata, gambar, dan diagram ke dalam idea matematika, (2) menjelaskan idea, situasi, dan relasi matematik, secara lisan dan tulisan dengan benda nyata, gambar, grafik dan aljabar, (3) menyatakan peristiwa sehari-hari dalam bahasa atau simbol matematika, (4) mendengarkan, berdiskusi, dan menulis tentang matematika, (5) membaca dengan pemahaman suatu presentasi Matematika tertulis, (6) membuat konjektur, menyusun argumen, merumuskan definisi dan generalisasi, (7) menjelaskan dan membuat pertanyaan matematika yang telah dipelajari.
\end{abstract}

Kata Kunci : Komunikasi educatif, komunikasi efektif, dan komunikasi dalam pembelajaran matematika.

Learning activity is a process of communication to convey a message from educators to students, aims to be well received messages and affect the understanding of the formation and behavior change. Educational communication in mathematics learning becomes a factor that also affects the success of the mathematics learning activities. Communication learning can be effective if there is a two-way flow of information between the response of the communicator and the communicant. There are at least five aspects that need to be understood in establishing effective communication, namely: clarity, accuracy, context, a clear systematic, and cultural communicator or communicant. Communicating mathematics, required ability to communicate effectively. Both teachers and students in learning mathematics are expected to communicate mathematical thinking orally and in writing, 
coherently and clearly, using the language of mathematics to express ideas precisely, mathematical thinking through communication manage, analyze and evaluate the mathematical thinking of their students. It is intended to make students capable of effective communication in: ( 1 ) connecting real objects, drawings, and diagrams into mathematical ideas, ( 2 ) explain the idea, situation, and mathematical relationships, orally and in writing with real objects, pictures, graphics and algebra, ( 3 ) states a daily occurrence in the language or mathematical symbols, ( 4 ) listen, discuss, and write about mathematics, ( 5 ) read with understanding a written presentation mathematics, ( 6 ) make conjectures, formulate arguments, formulate definition and generalization, ( 7 ) to explain and make math questions that have been studied.

Key words : Communication educatif, effective communication, and communication in learning mathematics

\section{Pendahuluan}

Upaya peningkatan kualitas sumber daya manusia merupakan bagian yang terpisahkan dari upaya peningkatan kualitas pendidikan yang saat ini sedang gencargencarnya dilaksanakan dan menjadi harapan masyarakat, bangsa dan negara Indonesia. Wujud dari proses pendidikan yang bersentuhan langsung dengan sasaran adalah berupa kegiatan belajar mengajar pada setiap jenis dan satuan pendidikan. Terciptanya kualitas kegiatan belajar mengajar atau sering disebut dengan kualitas proses pembelajaran tentu saja akan mempengaruhi terciptanya kualitas pendidikan yang output-nya berupa sumber daya manusia.

Kegiatan pembelajaran merupakan proses transformasi pesan edukatif berupa materi belajar dari sumber belajar kepada peserta didik. Dalam pembelajaran terjadi proses komunikasi untuk menyampaikan pesan dari pendidik kepada peserta didik. Proses ini bertujuan agar pesan dapat diterima dengan baik dan berpengaruh terhadap pemahaman serta terbentuknya perubahan tingkah laku. Mencapai keberhasilan kegiatan pembelajaran sangat tergantung kepada efektifitas proses komunikasi yang terjadi dalam pembelajaran melalui interaksi edukatif antara guru dan siswa. Baik melalui proses pembelajaran maupun dalam pergaulannya dilingkungan pendidikan.

Komunikasi edukatif dalam pembelajaran menjadi faktor yang juga berpengaruh terhadap keberhasilan kegiatan pembelajaran. Pada dasarnya komunikasi merupakan proses penyampaian informasi dari pemberi pesan kepada penerima pesan. Proses komunikasi berlangsung dengan baik jika komunikator menyampaikan informasi atau pesan kepada penerima dengan cara yang baik atau menggunakan media komunikasi agar pesan yang disampaikan dapat diterima dan dipahami dengan baik oleh penerima pesan (audience).

Proses komunikasi berlangsung pada suatu komunitas baik umum maupun khusus, termasuk pada kegiatan pembelajaran dalam kelas. Komunikasi dalam kegiatan pembelajaran terjadi antara guru dengan siswa dengan mengkomunikasikan pesan berupa ide atau gagasan atau materi pelajaran. Proses komunikasi tersebut 
diharapkan dapat berimplikasi pada kemampuan siswa untuk mentransfer pengetahuaan yang dikomunikasikan guru selama berlangsungnya kegiatan pembelajaran.

Oleh karena itu, komunikasi merupakan faktor penting dalam lingkungan pendidikan dewasa ini, sebab kehadiran komunikasi merupakan syarat utama terjadinya hubungan antara seorang dengan orang yang lain, guru dengan siswa, guru dengan guru, guru dengan orang tua dan lain sebagainya. Meskipun beberapa kalangan pembelajar meragukan kemampuan "komunikasi" sebagai satu-satunya alat yang dapat dipergunakan dalam menyelesaikan berbagai macam masalah belajar siswa. Namun untuk meyakinkan ketepatan penyelesaian masalah tersebut, maka penerapan komunikasi antara pribadi guru dengan siswa sebagai suatu kegiatan yang tepat, karena memandang guru sebagai person yang dinamik dan selalu berupaya untuk meningkatkan kemampuan kognitif, kematangan afektif dan keterampilan psikomotor peserta didik, baik untuk kepentingan pergaulannya dilingkungan pendidikan maupun lingkungan masyarakat. Begitu pentingnya komunikasi antar guru dan siswa atau antar setiap orang, terutama dalam rangka memahami pesan edukatif diantaranya, maka belajar berkomunikasi dan komunikasi untuk belajar perlu diuraikan dalam upaya menemukan atau lebih memperjelas makna berkomunikasi antar setiap individu. Dengan demikian tulisan ini bertujuan untuk memberikan kejelasan tentang belajar berkomunikasi dan komunikasi untuk belajar dalam pembelajaran matematika.

\section{Komunikasi dan Pembelajaran}

\section{Pengertian Komunikasi}

Banyak pendapat dari berbagai pakar mengenai definisi komunikasi, namun jika diperhatikan dengan seksama dari berbagai pendapat tersebut mempunyai maksud yang hampir sama. Menurut Hardjana, sebagaimana dikutip oleh Endang Lestari G (2003) secara etimologis komunikasi berasal dari bahasa Latin yaitu cum, sebuah kata depan yang artinya dengan, atau bersama dengan, dan kata umus, sebuah kata bilangan yang berarti satu. Dua kata tersebut membentuk kata benda communio, yang dalam bahasa Inggris disebut communion, yang mempunyai makna kebersamaan, persatuan, persekutuan, gabungan, pergaulan, atau hubungan. Karena untuk ber-communio diperlukan adanya usaha dan kerja, maka kata communion dibuat kata kerja communicare yang berarti membagi sesuatu dengan seseorang, tukar menukar, membicarakan sesuatu dengan orang, memberitahukan sesuatu kepada seseorang, bercakap-cakap, bertukar pikiran, berhubungan, atau berteman. Dengan demikian, komunikasi mempunyai makna pemberitahuan, pembicaraan, percakapan, pertukaran pikiran atau hubungan.

Definisi kontemporer menyatakan bahwa komunikasi berarti "mengirim pesan". Menurut (Effendy. 2003: 9) istilah komunikasi (communication) berasal dari kata 
latin communication, dan bersumber dari kata communis yang berarti memiliki makna yang sama. Berbicara mengenai definisi komunikasi tidak ada definisi yang salah dan benar secara absolute. Namun definisi kontemporer menyarankan bahwa komunikasi merujuk pada kalimat "mendiskusikan makna", "mengirim pesan" dan "penyampaian pesan lewat media". Apapun istilah yang dipakai, secara umum komunikasi mengandung pengertian "memberikan informasi, pesan, atau gagasan pada orang lain dengan maksud agar orang lain tersebut memiliki kesamaan informasi, pesan atau gagasan dengan pengirim pesan.

Evertt M. Rogers mendefinisikan komunikasi sebagai proses yang di dalamnya terdapat suatu gagasan yang dikirimkan dari sumber kepada penerima dengan tujuan untuk merubah perilakunya. Pendapat senada dikemukakan oleh Theodore Herbert, bahwa komunikasi merupakan proses dipindahkannya pengetahuan dari seseorang kepada orang lain, dengan maksud mencapai beberapa tujuan khusus. Selain itu, Wilbur Schramm mengemukakan pendapatnya bahwa, komunikasi merupakan tindakan melaksanakan kontak antara pengirim dan penerima, dengan bantuan pesan; pengirim dan penerima memiliki beberapa pengalaman bersama yang memberi arti pada pesan dan simbol yang dikirim oleh pengirim, dan diterima serta ditafsirkan oleh penerima. (Suranto : 2005)

Berdasarkan definisi yang telah diuraikan di atas dapat diambil pemahaman bahwa :

a. Komunikasi pada dasarnya merupakan suatu proses penyampaian informasi ; Dilihat dari sudut pandang ini, kesuksesan komunikasi tergantung kepada desain pesan atau informasi dan cara penyampaiannya. Menurut konsep ini pengirim dan penerima pesan tidak menjadi komponen yang menentukan.

b. Komunikasi adalah proses penyampaian gagasan dari seseorang kepada orang lain. Pengirim pesan atau komunikator memiliki peran yang paling menentukan dalam keberhasilan komumikasi, sedangkan komunikan atau penerima pesan hanya sebagai objek yang pasif.

c. Komunikasi diartikan sebagai proses penciptaan arti terhadap gagasan atau ide yang disampaikan. Pemahaman ini menempatkan tiga komponen yaitu pengirim, pesan, dan penerima pesan pada posisi yang seimbang. Proses ini menuntut adanya proses encoding oleh pengirim dan decoding oleh penerima, sehingga informasi dapat bermakna.

\section{Pengertian Pembelajaran}

Sardiman AM (2005) menyebut istilah pembelajaran dengan interaksi edukatif. Menurut Sardiman AM bahwa, yang dianggap interaksi edukatif adalah interaksi yang dilakukan secara sadar dan mempunyai tujuan untuk mendidik, dalam rangka mengantar peserta didik ke arah kedewasaannya. Pembelajaran merupakan proses yang berfungsi membimbing para peserta didik di dalam kehidupannya, yakni membimbing mengembangkan diri sesuai dengan tugas perkembangan yang harus dijalani. Proses edukatif memiliki ciri-ciri : (a). ada tujuan yang ingin dicapai ; (b). 
ada pesan yang akan ditransfer; (c). ada pelajar ; (d). ada guru ; €. ada metode ; (f). ada situasi ada penilaian.

Terdapat beberapa faktor yang secara langsung berpengaruh terhadap proses pembelajaran, yaitu pengajar, peserta didik (siswa/mahasiswa), sumber belajar, alat belajar, dan kurikulum (Once Kurniawan : 2005). Pembelajaran merupakan suatu sistem yang di dalamnya terdiri dari komponen-komponen sistem instruksional, yaitu komponen pesan, orang, bahan, peralatan, teknik, dan latar atau lingkungan.

Suatu sistem instruksional diartikan sebagai kombinasi komponen sistem instruksional dan pola pengelolaan tertentu yang disusun sebelumnya di saat mendesain atau mengadakan pemilihan, dan di saat menggunakan, untuk mewujudkan terjadinya proses belajar yang berarah tujuan dan terkontrol, dan yang : a) didesain untuk mencapai kompetensi tertentu atau tingkah laku akhir dari suatu pembelajaran; b) meliputi metodologi instruksional, format, dan urutan sesuai desain; c) mengelola kondisi tingkah laku; d) meliputi keseluruhan prosedur pengelolaan; e) dapat diulangi dan diproduksi lagi; f) telah dikembangkan mengikuti prosedur; dan g) telah divalidasi secara empirik. (Yusuf Hadi M, dkk.:1986)

Dengan demikian pembelajaran dapat dimaknai sebagai interaksi antara pendidik dengan peserta didik yang dilakukan secara sengaja dan terencana serta memiliki tujuan yang positif. Keberhasilan pembelajaran harus didukung oleh komponenkomponen instuksional yang terdiri dari pesan berupa materi belajar, penyampai pesan yaitu pengajar, bahan untuk menuangkan pesan, peralatan yang mendukung kegiatan belajar, teknik atau metode yang sesuai, serta latar atau situasi yang kondusif bagi proses pembelajaran.

\section{Proses Komunikasi dalam Pembelajaran}

\section{Proses Komunikasi}

Komunikasi adalah suatu proses, bukan sesuatu yang bersifat statis. Komunikasi memerlukan tempat, dinamis, menghasilkan perubahan dalam usaha mencapai hasil, melibatkan interaksi bersama, serta melibatkan suatu kelompok. Pengirim pesan melakukan encode, yaitu memformulasikan pesan yang akan disampaikannya dalam bentuk code yang sedapat mungkin dapat ditafsirkan oleh penerima pesan. Penerima pesan kemudian menafsirkan atau men-decode code yang disampaikan oleh pengirim pesan. Berhasil tidaknya komunikasi atau tercapai tidaknya tujuan komunikasi tergantung dari ketiga komponen tersebut.

Dilihat dari prosesnya, komunikasi dibedakan atas komunikasi verbal dan komunikasi nonverbal. Komunikasi verbal adalah komunikasi dengan menggunakan bahasa, baik bahasa tulis maupun bahasa lisan. Sedangkan komunikasi nonoverbal adalah komunikasi yang menggunakan isyarat, gerak gerik, gambar, lambing, mimik 
muka, dan sejenisnya. Ketercapaian tujuan merupakan keberhasilan komunikasi. Keberhasilan komunikasi menurut IGAK Wardani (2005) tergantung pada faktorfaktor, yaitu ; komunikator, pesan yang disampaikan, komunikan, konteks, dan system penyampaian.

Peran faktor-faktor tersebut dalam mencapai keberhasilan komunikasi dapat diuraikan sebagai berikut : (a) Komunikator (Pengirim Pesan) ; merupakan sumber dan pengirim pesan. Kredibilitas komunikator yang membuat komunikan percaya terhadap isi pesan sangat berpengaruh terhadap keberhasilan komunikasi ; (b) Pesan yang disampaikan ; Pesan harus memiliki daya tarik tersendiri, sesuai dengan kebutuhan penerima pesan, adanya kesamaan pengalaman tentang pesan, dan ada peran pesan dalam memenuhi kebutuhan penerima, (c) Komunikan (Penerima Pesan) ; Agar komunikasi berjalan lancar, komunikan harus mampu menafsirkan pesan, sadar bahwa pesan sesuai dengan kebutuhannya, dan harus ada perhatian terhadap pesan yang diterima ; (d) Konteks ; Komunikasi berlangsung dalam setting atau lingkungan tertentu. Lingkungan yang kondusif sangat mendukung keberhasilan komunikasi ; dan (e). Sistem Penyampaian ; Sistem penyampaian berkaitan dengan metode dan media. Metode dan media yang digunakan dalam proses komunikasi harus disesuaikan dengan kondisi atau karakterisitik penerima pesan.

Dengan demikian proses komunikasi dapat berlangsung satu arah dan dua arah. Komunikasi yang dianggap efektif adalah komunikasi yang menimbulkan arus informasi dua arah, yaitu dengan munculnya feedback dari pihak penerima pesan. Dalam proses komunikasi yang baik akan terjadi tahapan pemaknaan terhadap pesan (meaning) yang akan disampaikan oleh komunikator, kemudian komunikator melakukan proses encoding, yaitu interpretasi atau mempersepsikan makna dari pesan tadi, dan selanjutnya dikirim kepada komunikan melalui channel yang dipilih. Pihak komunikan menerima informasi dari pengirim dengan melakukan proses decoding, yaitu menginterpretasi pesan yang diterima, dan kemudian memahaminya sesuai dengan maksud komunikator. Sinkronisasi pemahaman antara komunikan dengan komunikator akan menimbulkan respon yang disebut dengan umpan balik.

\section{Belajar Berkomunikasi yang Efektif}

Sebagai kegiatan mentransfer sebuah informasi, komunikasi dapat diimplementasikan baik secara lisan maupun tulisan, dan tidak semua orang mampu melakukan komunikasi dengan baik. Terkadang ada orang yang mampu menyampaikan semua informasi secara lisan tetapi tidak secara tulisan ataupun sebaliknya. Disini perlu menganalisis permasalahan, " bagaimanakah caranya agar kita mampu melakukan komunikasi yang baik, komunikasi yang dua arah, komunikasi yang efektif, sehingga target informasi yang harus disampaikan ataupun diserap sesuai dengan harapan?" Jawaban atas permasalahan ini, bahwa mencapai 
kemampuan komunikasi yang baik dan efektif diperlukan suatu kegiatan belajar atau latihan secara berkesinambungan sehingga mencapai keterampilan berkomunikasi.

Keterampilan dalam berkomunikasi secara efektif dapat dipelajari dan dikuasai dengan latihan rutin dan berkesinambungan secara terus menerus. Keterampilan yang harus dimiliki dalam melakukan komunikasi efektif adalah keterampilan mendengarkan dan bertanya. Dalam proses berkomunikasi, seseorang harus mampu mendengarkan dan memahaminya dengan baik. Kemudian mengajukan pertanyaanpertanyaan yang saling memiliki keterkaitan dan mengarah pada suatu solusi atau ketenangan untuk masing-masing pihak. Sehingga tujuan utama dalam komunikasi yang efektif adalah sebuah win-win solution. Tak ada satupun orang yang mau disalahkan, inilah konsep dasar dari komunikasi efektif.

Komunikasi efektif dapat dilakukan oleh setiap orang. Jika ada yang merasa tidak mampu, hal ini lebih karena masalah pembiasaan saja. Melatih orang berkomunikasi secara efektif bisa dilakukan dengan langsung pada prakteknya. Melalui praktek latihan berkomunikasi secara terus-menerus dapat membantu setiap individu untuk mencapai kemampuan komunikasi efektif, dan dapat menunjukan kepribadian yang berkarakter positif.

\section{Desain Komunikasi dalam Pembelajaran}

Pembelajaran sebagai proses komunikasi dilakukan secara sengaja dan terencana, untuk mencapai tujuan yang telah ditetapkan sebelumnya. Agar pesan pembelajaran yang ingin ditransformasikan dapat tersampaikan dengan baik, Abdul Gaffur (2006) menyarankan kepada guru/dosen perlu mendesain pesan pembelajaran yang akan diterapkannya dengan memperhatikan prinsip-prinsip sebagai berikut :

a. Kesiapan dan motivasi ; Kesiapan disini mencakup kesiapan mental dan fisik. Untuk mengetahui kesiapan mahasiswa dalam menerima belajar dapat dilakukan dengan tes diagnostik atau tes prerequisite. Motivasi terdiri dari motivasi internal dan eksternal, yang dapat ditumbuhkan dengan pemberian penghargaan, hukuman, serta deskripsi mengenai keuntungan dan kerugian dari pembelajaran yang akan dilakukan.

b. Alat Penarik Perhatian ; Pada dasarnya perhatian/konsentrasi manusia adalah jalang, sering berubah-ubah dan berpindah-pindah (tidak focus). Sehingga dalam mendesain pesan belajar, dosen harus pandai-pandai membuat daya tarik, untuk mengendalikan perhatian mahasiswa pada saat belajar. Pengendali perhatian yang dimaksud dapat berupa : warna, efek musik, pergerakan/perubahan, humor, kejutan, ilustrasi verbal dan visual, serta sesuatu yang aneh.

c. Partisipasi Aktif Siswa ; Dosen harus berusaha membuat peserta didik aktif dalam proses pembelajaran. Untuk menumbuhkan keaktifan mahasiswa harus dimunculkan rangsangan-rangsangan, dapat berupa : tanya jawab, praktik dan latihan, drill, membuat ringkasan, kritik dan komentar, serta pemberian proyek (tugas). 
d. Pengulangan ; Agar peserta didik dapat menerima dan memahami materi dengan baik, maka penyampaian materi sebaiknya dilakukan berulang kali. Pengulangan dapat berupa : pengulangan dengan metode dan media yang sama, pengulangan dengan metode dan media yang berbeda, preview, overview, atau penggunaan isyarat.

e. Umpan Balik ; Dalam proses pembelajaran, sebagaimana yang terjadi pada komunikasi, adanya feedback merupakan hal yang penting. Umpan balik yang tepat dari dosen dapat menjadi pemicu semangat bagi mahasiswa. Umpan balik yang diberikan dapat berupa : informasi kemajuan belajar siswa, penguatan terhadap jawaban benar, meluruskan jawaban yang keliru, memberi komentar terhadap pekerjaan siswa, dan dapat pula memberi umpan balik yang menyeluruh terhadap performansi mahasiswa.

f. Menghindari Materi yang Tidak Relevan ; Agar materi pelajaran yang diterima peserta didik tidak menimbulkan kebingungan atau bias dalam pemahaman, maka sedapat mungkin harus dihindari materi-materi yang tidak relevan dengan topik yang dibicarakan. Untuk itu dalam mendesain pesan perlu memperhatikan bahwa : yang disajikan hanyalah informasi yang penting, memberikan outline materi, memberikan konsep-konsep kunci yang akan dipelajari, membuang informasi distraktor, dan memberikan topik diskusi.

\section{Komunikasi Efektif dalam Pembelajaran}

Komunikasi dikatakan efektif apabila terdapat aliran informasi dua arah antara komunikator dan komunikan dan informasi tersebut sama-sama direspon sesuai dengan harapan kedua pelaku komunikasi tersebut. Setidaknya terdapat lima aspek yang perlu dipahami dalam membangun komunikasi yang efektif, yaitu :

a. Kejelasan; Hal ini dimaksudkan bahwa dalam komunikasi harus menggunakan bahasa dan mengemas informasi secara jelas, sehingga mudah diterima dan dipahami oleh komunikan.

b. Ketepatan; Ketepatan atau akurasi ini menyangkut penggunaan bahasa yang benar dan kebenaran informasi yang disampaikan.

c. Konteks; Konteks atau sering disebut dengan situasi, maksudnya adalah bahwa bahasa dan informasi yang disampaikan harus sesuai dengan keadaan dan lingkungan dimana komunikasi itu terjadi.

d. Alur; Bahasa dan informasi yang akan disajikan harus disusun dengan alur atau sistematika yang jelas, sehingga pihak yang menerima informasi cepat tanggap

e. Budaya; Aspek ini tidak saja menyangkut bahasa dan informasi, tetapi juga berkaitan dengan tatakrama dan etika. Artinya dalam berkomunikasi harus menyesuaikan dengan budaya orang yang diajak berkomunikasi, baik dalam penggunaan bahasa verbal maupun nonverbal, agar tidak menimbulkan kesalahan persepsi. (Endang Lestari G : 2003)

Terkait dengan proses pembelajaran, komunikasi dikatakan efektif jika pesan yang dalam hal ini adalah materi pelajaran dapat diterima dan dipahami, serta 
menimbulkan umpan balik yang positif oleh peserta didik. Komunikasi efektif dalam pembelajaran harus didukung dengan keterampilan komunikasi antar pribadi yang harus dimiliki oleh seorang pendidik. Komunikasi antar pribadi merupakan komunikasi yang berlangsung secara informal antara dua orang individu. Komunikasi ini berlangsung dari hati ke hati, karena diantara keduabelah pihak terdapat hubungan saling mempercayai. Komunikasi antar pribadi akan berlangsung efektif apabila pihak yang berkomunikasi menguasai keterampilan komunikasi antar pribadi.

Dalam kegiatan belajar mengajar, komunikasi antar pribadi merupakan suatu keharusan, agar terjadi hubungan yang harmonis antara pengajar dengan peserta didik. Keefektifan komunikasi dalam kegiatan belajar mengajar ini sangat tergantung dari kedua belah pihak. Akan tetapi karena pengajar yang memegang kendali kelas, maka tanggung jawab terjadinya komunikasi dalam kelas yang sehat dan efektif terletak pada tangan pengajar. Keberhasilan pengajar dalam mengemban tanggung jawab tersebut dipengaruhi oleh keterampilannya dalam melakukan komunikasi.

Komunikasi yang efektif dalam proses pembelajaran sangat berdampak terhadap keberhasilan pencapaian tujuan. Komunikasi dikatakan efektif apabila terdapat aliran informasi dua arah antara komunikator dan komunikan dan informasi tersebut sama-sama direspon sesuai dengan harapan kedua pelaku komunikasi tersebut. Jika dalam pembelajaran terjadi komunikasi yang efektif antara pengajar dengan mahasiswa, maka dapat dipastikan bahwa pembelajaran tersebut berhasil. Sehubungan dengan hal tersebut, maka para pengajar, pendidik, atau instruktur pada lembaga-lembaga pendidikan atau pelatihan harus memiliki kemampuan komunikasi yang baik. Kemampuan komunikasi yang dimaksud dapat berupa kemampuan memahami dan mendesain informasi, memilih dan menggunakan saluran atau media, serta kemampuan komunikasi antar pribadi dalam proses pembelajaran.

\section{Kemampuan Komunikasi Matematika}

Untuk mengembangkan kemampuan berkomunikasi, orang dapat menyampaikan dengan berbagai bahasa termasuk bahasa matematis. Kemampuan komunikasi matematis dapat diartikan sebagai suatu kemampuan siswa dalam menyampaikan sesuatu yang diketahuinya melalui peristiwa dialog atau saling hubungan yang terjadi di lingkungan kelas, dimana terjadi pengalihan pesan. Pesan yang dialihkan berisi tentang materi matematika yang dipelajari siswa, misalnya berupa konsep, rumus, atau strategi penyelesaian suatu masalah. Pihak yang terlibat dalam peristiwa komunikasi di dalam kelas adalah guru dan siswa. Cara pengalihan pesannya dapat secara lisan maupun tertulis. 
Di dalam proses pembelajaran matematika di kelas, komunikasi gagasan matematika bisa berlangsung antara guru dengan siswa, antara buku dengan siswa, dan antara siswa dengan siswa. Menurut Hiebert setiap kali kita mengkomunikasikan gagasangagasan matematika, kita harus menyajikan gagasan tersebut dengan suatu cara tertentu. Ini merupakan hal yang sangat penting, sebab bila tidak demikian, komunikasi tersebut tidak akan berlangsung efektif. Gagasan tersebut harus disesuaikan dengan kemampuan orang yang kita ajak berkomunikasi. Kita harus mampu menyesuaikan dengan sistem representasi yang mampu mereka gunakan. Tanpa itu, komunikasi hanya akan berlangsung dari satu arah dan tidak mencapai sasaran.

Sedangkan indikator kemampuan siswa dalam komunikasi matematis pada pembelajaran matematika berdasarkan NCTM (1989: 214) dapat dilihat dari: (1) Kemampuan mengekspresikan ide-ide matematika melalui lisan, tertulis, dan mendemonstrasikannya serta menggambarkannya secara visual; (2) Kemampuan memahami, menginterpretasikan, dan mengevaluasi ide-ide Matematika baik secara lisan maupun dalam bentuk visual lainnya;

(3) Kemampuan dalam menggunakan istilah-istilah, notasi-notasi Matematika dan struktur-strukturnya untuk menyajikan ide, menggambarkan hubungan-hubungan dan model-model situasi.

Within (1992) menyatakan kemampuan komunikasi menjadi penting ketika diskusi antar siswa dilakukan, dimana siswa diharapkan mampu menyatakan, menjelaskan, menggambarkan, mendengar, menanyakan dan bekerjasama sehingga dapat membawa siswa pada pemahaman yang mendalam tentang matematika. Anak-anak yang diberikan kesempatan untuk bekerja dalam kelompok dalam mengumpulkan dan menyajikan data, mereka menunjukkan kemajuan baik di saat mereka saling mendengarkan ide yang satu dan yang lain, mendiskusikannya bersama kemudian menyusun kesimpulan yang menjadi pendapat kelompoknya. Kemampuan komunikasi matematis siswa dapat dilihat dari kemampuan : (1) menghubungkan benda nyata, gambar, dan diagram ke dalam idea matematika, (2) menjelaskan idea, situasi, dan relasi matematik, secara lisan dan tulisan dengan benda nyata, gambar, grafik dan aljabar, (3) menyatakan peristiwa sehari-hari dalam bahasa atau simbol matematika, (4) mendengarkan, berdiskusi, dan menulis tentang matematika, (5) membaca dengan pemahaman suatu presentasi Matematika tertulis, membuat konjektur, menyusun argumen, merumuskan definisi dan generalisasi, (7) menjelaskan dan membuat pertanyaan matematika yang telah dipelajari.

Secara umum, matematika dalam ruang lingkup komunikasi mencakup keterampilan/kemampuan menulis, membaca, discussing and assessing, dan wacana (discourse). Peressini dan Bassett (dalam NCTM,1966) berpendapat bahwa tanpa komunikasi dalam matematika kita akan memiliki sedikit keterangan, data, dan fakta tentang pemahaman siswa dalam melakukan proses dan aplikasi matematika. Ini berarti, komunikasi dalam matematika menolong guru memahami kemampuan 
sisiwa dalam menginterpretasi dan mengekspresikan pemahamannya tentang konsep dan proses matematika yang mereka pelajari Dalam bagian lain, Lindquist (NCTM, 1996) berpendapat, jika kita sepakat bahwa matematika itu merupakan suatu bahasa dan bahasa tersebut sebagai bahasan terbaik dalam komunitasnya, maka mudah dipahami bahwa komunikasi merupakan esensi dari mengajar, belajar, dan mengassess matematika.

Jadi jelaslah bahwa komunikasi dalam matematika merupakan kemampuan mendasar yang harus dimiliki pelaku dan pengguna matematika selama belajar, mengajar, dan meng-assess matematika.

Menurut Lang \& Evans (2006) seorang guru perlu menjadi seorang komunikator yang efektif. Guru harus berkomunikasi dengan siswa, guru lain, staf administrasi, orang tua siswa dan masyarakat luar. Komunikasi yang efektif menyaratkan berbagai macam pengetahuan/ketrampilan, antara lain pengetahuan tentang diri sendiri, mata pelajaran, pendekatan pembelajaran untuk siswa, dan ketrampilan berkomunikasi antar perorangan. Kauchak dan Eggen (dalam Lang \&Evans, 2006), berdasarkan pada suatu penelitian, telah mengidentifikasi 5 komponen dari komunikasi yang efektif, yaitu: (1) Istilah yang tepat; (2) Percakapan yang "nyambung"; (3) Isyarat untuk transisi; (4) Penekanan; dan (5) Kesesuaian antara tindak-tanduk verbal dan non verbal.

Dalam matematika, komunikasi memegang peranan yang sangat penting. Komunikasi menjadi bagian yang esensial dari matematika dan pendidikan matematika. Komunikasi adalah cara untuk berbagi (sharing) gagasan dan mengklarifikasi pemahaman. Melalui komunikasi, gagasan-gagasan menjadi objekobjek refleksi, penghalusan, diskusi, dan perombakan. Proses komunikasi juga membantu membangun makna dan kelanggengan untuk gagasan-gagasan, serta juga menjadikan gagasan-gagasan itu diketahui publik (NCTM, 2000).

Menurut NCTM Program Standards (2003), seorang calon guru matematika haruslah mampu mengomunikasikan pikiran matematisnya secara lisan dan tertulis kepada teman-temannya, para dosen, dan kepada yang lainnya, dengan indicatorindikator, mampu: (1) Mengomunikasikan pikiran matematisnya secara koheren dan jelas kepada teman-temannya, para dosen, dan kepada yang lainnya; (2) Menggunakan bahasa matematika untuk mengekspresikan ide/gagasannya secara tepat; (3) Mengelola pikiran matematisnya melalui komunikasi; dan (4) Menganalisis dan mengevaluasi pikiran matematis dan strategi-strategi orang lain.

\section{Penutup}

Pembelajaran sebagai subset dari proses pendidikan harus mampu memberikan kontribusi terhadap peningkatan kualitas pendidikan, yang pada ujungnya akan 
berpengaruh terhadap peningkatan kualitas sumber daya manusia. Agar pembelajaran dapat mendukung peningkatan mutu pendidikan, maka dalam proses pembelajaran harus terjadi komunikasi yang efektif, yang mampu memberikan kefahaman mendalam kepada peserta didik atas edukatif yang diberikan. Komunikasi efektif dalam pembelajaran merupakan proses transformasi pesan berupa ilmu pengetahuan dan teknologi dari pendidik kepada peserta didik, dimana peserta didik mampu memahami maksud pesan sesuai dengan tujuan yang telah ditentukan, sehingga menambah wawasan ilmu pengetahuan dan teknologi serta menimbulkan perubahan tingkah laku menjadi lebih baik. Sebagai pihak yang paling bertanggungjawab terhadap berlangsungnya komunikasi yang efektif dalam pembelajaran, guru/dosen dituntut memiliki kemampuan berkomunikasi dan memahami lima aspek dalam membangun komunikasi yang efektif, yaitu ; kejelasan, ketepatan, konteks (sesuai situasi), alurnya jelas, dan kemampuan memahami budaya, sehingga menghasilkan proses pembelajaran yang efektif.

Begitu pula dengan mengkomunikasikan matematika, sangat diperlukan kemampuan berkomunikasi yang efektif, terutama guru dan siswa dalam pembelajaran matematika. Guru dalam pembelajaran matematika diharapkan mampu mengomunikasikan pikiran matematisnya secara lisan dan tertulis, secara koheren dan jelas, menggunakan bahasa matematika untuk mengekspresikan ide/gagasannya secara tepat, mengelola pikiran matematisnya melalui komunikasi, menganalisis dan mengevaluasi pikiran matematis siswanya. Sebagai out put-nya siswa diharapkan berkemampuan komunikasi secara efektif dalam : (1) menghubungkan benda nyata, gambar, dan diagram ke dalam idea matematika, (2) menjelaskan idea, situasi, dan relasi matematik, secara lisan dan tulisan dengan benda nyata, gambar, grafik dan aljabar, (3) menyatakan peristiwa sehari-hari dalam bahasa atau simbol matematika, (4) mendengarkan, berdiskusi, dan menulis tentang matematika, (5) membaca dengan pemahaman suatu presentasi Matematika tertulis, (6) membuat konjektur, menyusun argumen, merumuskan definisi dan generalisasi, (7) menjelaskan dan membuat pertanyaan matematika yang telah dipelajari.

\section{DAFTAR PUSTAKA}

Effendy, Onong Uchjana. (2003). Ilmu komunikasi; Teori dan Praktek. Bandung: Rosda Karya.

Hafied Changara, (1998). Pengantar Ilmu Komunikasi. Jakarta : Rajawali Pers.

Lestari G, Endang dan Maliki, MA. (2003). Komunikasi yang Efektif. Lembaga Administrasi Negara. Jakarta.

Lang, H. R, \& Evans, D.N. (2006). Models, Strategis, and Methods for Effective Teaching. USA: Pearson Education, Inc.

National Council of Teachers of Mathematics. (2000). Prinsiples and Standards for School Mathematics. Reston: NCTM. 
National Council of Teachers of Mathematics. (2003). NCTM Program Standards.Programs for Initial Preparation of Mathematics Teachers. Standards for Secondary Mathematics Teachers. [Online]. Tersedia: http://www.nctm.org/uploadedFiles/Math_Standards/ [ 10 Maret 2008].

NCTM. (1989). Curriculum and Evaluation Standards for School Mathematics. Reston, VA : NCTM

Sardiman AM. (2005). Interaksi dan Motivasi Belajar Mengajar. Rajawali Press. Jakarta.

Suranto. (2005). Komunikasi Perkantoran. Media Wacana. Yogyakarta

Sardiman AM. (2005). Interaksi dan Motivasi Belajar Mengajar. Rajawali Press. Jakarta.

Wardani, IGAK. (2005). Dasar-Dasar Komunikasi dan Keterampilan Dasar Mengajar. PAU-DIKTI DIKNAS. Jakarta.

Within. (1992). Mathematics Task Centre; Proffesional Development and Problem Solving. In J. 